\title{
Multiple Roles of Mitochondria in Aging Processes
}

\author{
M. CEDIKOVA ${ }^{1,2}$, P. PITULE ${ }^{2,3}$, M. KRIPNEROVA ${ }^{4}$, M. MARKOVA ${ }^{1}$, J. KUNCOVA ${ }^{1,2}$ \\ ${ }^{1}$ Department of Physiology, Faculty of Medicine in Pilsen, Charles University, Pilsen, Czech \\ Republic, ${ }^{2}$ Biomedical Center, Faculty of Medicine in Pilsen, Charles University, Pilsen, Czech \\ Republic, ${ }^{3}$ Department of Histology and Embryology, Faculty of Medicine in Pilsen, Charles \\ University, Pilsen, Czech Republic, ${ }^{4}$ Department of Biology, Faculty of Medicine in Pilsen, Charles \\ University, Pilsen, Czech Republic
}

Received March 27, 2016

Accepted October 26, 2016

\begin{abstract}
Summary
Aging is a multifactorial process influenced by genetic factors, nutrition, and lifestyle. According to mitochondrial theory of aging, mitochondrial dysfunction is widely considered a major contributor to age-related processes. Mitochondria are both the main source and targets of detrimental reactions initiated in association with age-dependent deterioration of the cellular functions. Reactions leading to increased reactive oxygen species generation, mtDNA mutations, and oxidation of mitochondrial proteins result in subsequent induction of apoptotic events, impaired oxidative phosphorylation capacity, mitochondrial dynamics, biogenesis and autophagy. This review summarizes the major changes of mitochondria related to aging, with emphasis on mitochondrial DNA mutations, the role of the reactive oxygen species, and structural and functional changes of mitochondria.
\end{abstract}

\section{Key words}

Mitochondria • Aging • mtDNA • Oxidative stress

\section{Corresponding author}

J. Kuncová, Department of Physiology, Biomedical Center, Faculty of Medicine in Pilsen, Charles University, Alej Svobody 76, 32300 Plzeň, Czech Republic. E-mail: jitka.kuncova@lfp.cuni.cz

\section{Introduction}

Progressive aging of the elderly population is an increasingly important feature of societies in the developed countries (Olshansky 2013). In biology, aging is defined as an age-dependent or age-progressive decline in the intrinsic physiological function, leading to an increase in age-specific mortality rate and a decrease in age-specific reproductive rate (Anton et al. 2015, Basaria 2013, Fulop et al. 2010). Human aging starts after the third decade and is commonly associated with the accumulation of physical, psychological, and social changes leading to general decline in wellness, reduction in mobility (which is critical factor impacting the quality of life) and the onset of many age-related diseases including atherosclerosis, heart disease, hypertension, cancer, arthritis, cataract, Alzheimer's disease, and type 2 diabetes mellitus (Baumgartner et al. 1998, Liu 2014). In spite of intense research, the mechanisms that underlie age-dependent changes are still largely unknown (Barja 2013).

Mitochondrial dysfunction has long been considered a major contributor to aging and age-related diseases (for a review, see Chistiakov et al. 2014). With advanced age, mitochondrial dynamics, biogenesis, and oxidative phosphorylation capacity decrease, whereas mitochondrial DNA (mtDNA) damage, production of reactive oxygen species (ROS), induction of apoptotic events, and oxidation of numerous mitochondrial proteins leading to formation of protein-protein cross-linkages and protein fragmentation progressively increase (reviewed in Chistiakov et al. 2014, Gonzalez-Freire et al. 2015). Accumulation of ROS and oxidative damage have been linked to multiple pathologies, including neurodegenerative diseases, diabetes, cancer, and 
premature aging. In 1956, Harman postulated free radical theory of aging stating that aging process depends on ROS production leading to oxidative damage and subsequent malfunction of nucleic acids, proteins and lipids (Harman 1956). This theory was later extended to mitochondrial theory of aging suggesting that both the main source and target of oxygen and nitrogen radicals produced in association with aging processes are mitochondria (Payne and Chinnery 2015, Ziegler et al. 2015). Dysfunction of mitochondrial electrontransporting system leads to increased production of ROS, which results in mtDNA damage followed by mutations causing compromised mitochondrial protein function and further increase in production of oxygen and nitrogen radicals. Although this theory was challenged by some experimental observations documenting that at least in some species, reduced oxidative damage may not invariably prolong life span, excessive production of ROS related to mitochondrial malfunction is still considered an important factor contributing to accelerated aging process (Avantaggiato et al. 2015, López-Lluch et al. 2015). In addition, mitochondrial health and aging may be affected by subject parameters like physical activity history (Barrientos et al. 1996, Gnaiger 2009, Lanza et al. 2008), age (Bua et al. 2006), caloric restriction (Schiff et al. 2011), drugs (Heller et al. 2012), and various comorbidities including obesity (Boudina and Graham 2014), sarcopenia (Figueiredo et al. 2008, Marzetti et al. 2010, Moore et al. 2010), hypertriglyceridemia, dyslipoproteinemia, insulin resistance, abnormal glucose tolerance, and hypertension (Bonomini et al. 2015).

In this review, we briefly revise the major changes of mitochondria related to aging, with emphasis on: i) structural and functional changes of mitochondria, ii) mitochondrial DNA mutations, and iii) the role of ROS.

\section{Overview of mitochondria - structure and functions}

About 1.5 billion years ago, mitochondria (from Greek mitos (thread-like) and khondros (grain or granule)) and eukaryotic cells established a symbiotic relationship. Mitochondria are subcellular, selfautonomous, highly dynamic and pleomorphic organelles surrounded by double-membrane system. They contain their own genetic system and sophisticated enzymatic machinery enabling many distinct metabolic processes (Wang et al. 2010). They are found in almost all human cells with exception of mature erythrocytes (Logan 2006, Zhang et al. 2012).

The primary function of mitochondria is to produce adenosine triphosphate (ATP) by the process of oxidative phosphorylation through the respiratory system (they synthesize more than 95\% ATP for cellular utilization). General view of the mitochondrial respiratory system is shown in Figure 1A. This system is composed of four respiratory complexes (I-IV) localized in the inner mitochondrial membrane, two mobile carriers (coenzyme Q and cytochrome $c$ ), and ATP synthase. On complexes I and II, reduced coenzymes, nicotinamide adenine dinucleotide (NADH) and flavin adenine dinucleotide $\left(\mathrm{FADH}_{2}\right)$ are oxidized, respectively. Reduced coenzymes are generated by various dehydrogenases particularly in tricarboxylic acid cycle. The electrons released by the oxidation of reduced coenzymes are transferred through the respiratory complexes to the molecular oxygen providing energy to pump protons across the inner mitochondrial membrane (complexes I, III and IV). Created electrochemical potential (proton-motive force) is then used by ATP synthase to form ATP from ADP and $\mathrm{P}_{\mathrm{i}}$ (Benard et al. 2006, Zeviani and Di Donato 2004).

In addition to energy, mitochondria also generate ROS and represent the major source of their cellular production. Leakage of electrons, mainly from complexes I and III, leads to one-electron reduction of oxygen to form superoxide anion that is the precursor of most ROS and a mediator in oxidative chain reactions. Superoxide anion then undergoes dismutation catalyzed by superoxide dismutase thus producing longer-lived and membrane permeant hydrogen peroxide. This molecule can be fully or partially reduced to water or hydroxyl radical, respectively (Turrens 2003, Murphy 2009). Under normal conditions, ROS are maintained at physiological levels by several endogenous systems of antioxidant enzymes, such as superoxide dismutase (SOD), catalase, glutathione peroxidases and glutathione reductase (Dai et al. 2014). Schematic view of ROS production is shown in Figure 2.

Besides this, mitochondria also play an essential role in amino acid and lipid metabolism, calcium homeostasis, regulation of apoptosis, cell cycle regulation, and thermogenesis (Friedman and Nunnari 2014). 
A

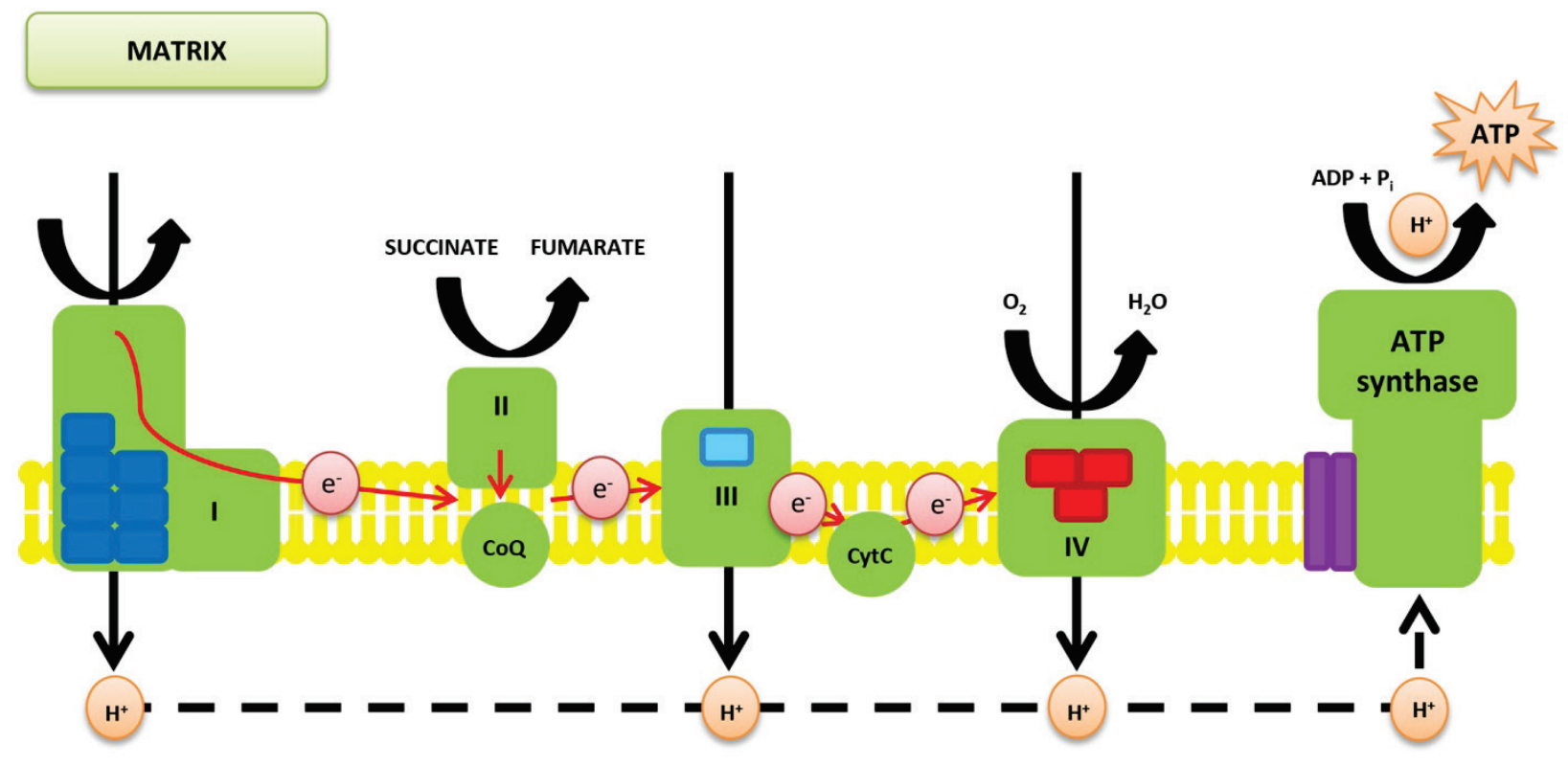

INTERMEMBRANE SPACE

$\mathrm{B}$

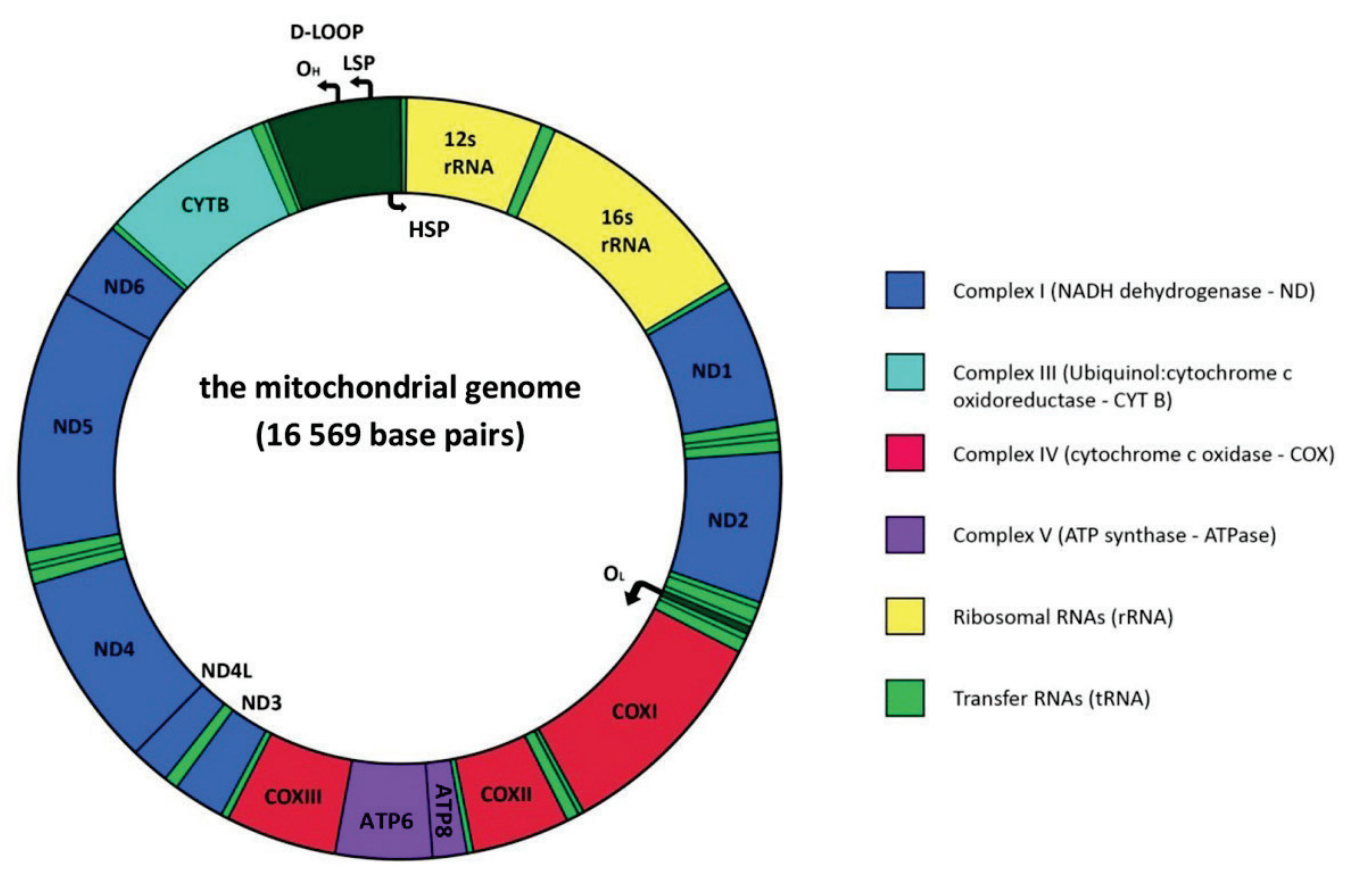

Fig. 1. General view of the mitochondrial respiratory system and genome. A. The respiratory system consists of four complexes (I - NADH dehydrogenase, II - succinate dehydrogenase, III - cytochrome $c$ reductase and VI - cytochrome $c$ oxidase) and ATP synthase. Subunits of complexes encoded by mtDNA are shown in same colors as in part B. CoQ - coenzyme Q, CytC - cytochrome $C$, $\mathrm{e}^{-}$- electron. B. mtDNA is schematized together with the encoded genes. The D-loop contains the promoters for transcription of the $H$ and $L$ strand $(H S P, L S P)$ as well as the origin of replication of the leading strand of mtDNA $\left(\mathrm{O}_{\mathrm{H}}\right)$. The color indicates to which part of the respiratory system the subunit-encoding gene belongs to. 


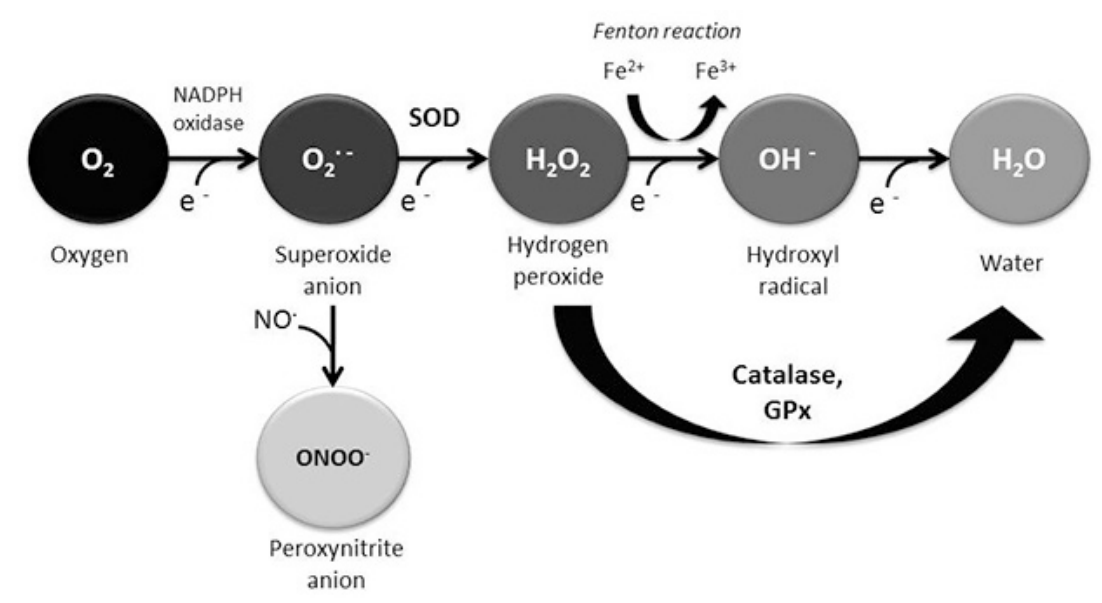

Fig. 2. Schematic representation of ROS production. In the course of metabolic processes are generated reactive oxygen and nitrogen species and this scheme shows the process of their transformation. $\mathrm{e}^{-}$- electron, $\mathrm{O}_{2}$ - oxygen, $\mathrm{O}_{2}{ }^{--}-$superoxide anion, $\mathrm{H}_{2} \mathrm{O}_{2}$ - hydrogen peroxide, $\mathrm{OH}^{-}-$ hydroxyl radical, $\mathrm{H}_{2} \mathrm{O}$ - water, $\mathrm{NO}$ - nitric oxide, $\mathrm{ONOO}^{-}$- peroxynitrite anion, SOD superoxide dismutase, GPx - glutathione peroxidase.

\section{Structural and functional changes of mitochondria associated with aging}

Mitochondria typically form a reticular network radiating from the nucleus. This network is regulated through the complex coordination of fission, fusion and distribution events and is essential to maintain normal mitochondrial functions (Palmer et al. 2011, Roy et al. 2015). Fusion processes are associated with the optimization of mitochondrial function by mixing of intramitochondrial components to dilute any damaged mtDNA and proteins, whereas fission events are associated with the removal of damaged mitochondria by selective mitochondrial autophagy (Papáčková and Cahová 2014). Once this balance is lost, various mitochondrial and cellular functions are changed as well (Terman et al. 2010).

A number of studies have demonstrated that aging is accompanied by a decrease in mitochondrial dynamics that leads to compromised function and formation of morphological alterations. In the skeletal muscle and brain, aging is associated with loss of mitochondria that are abnormally enlarged and more rounded in shape (Palomera-Avalos et al. 2016, Crane et al. 2010, Shigenaga et al. 1994, Terman et al. 2010). Beregi et al. (1988) showed that in the mitochondria of human and mouse skeletal muscle, in addition to abnormal size, inner membrane cristae were irregularly spaced, disrupted and replaced by lamellar, myelin-like structures with advancing age. On the other hand, Poggi et al. (1987) reported a decrease in mitochondrial size and mitochondrial percentage per fibre area when analyzed human $m$. vastus lateralis (Poggi et al. 1987). Changes in mitochondrial volume, shape or length seem to be a general feature of the aging process as they have been described not only in muscle or neuron, but also in the liver, bone, fibroblasts and mesenchymal stem cells derived from adipose tissue (Allen et al. 2015, Mahmoud and Hegazy 2016, Marycz et al. 2016, Shum et al. 2016, Yen et al. 1989).

Besides morphological changes, significant functional alterations were demonstrated in mitochondria during aging. An age-dependent mitochondrial dysfunction may comprise decreased electron transfer rates, increased $\mathrm{H}^{+}$permeability of the inner membrane, and impairment of the $\mathrm{H}^{+}$-driven ATP synthesis (Navarro and Boveris 2007, Porter et al. 2015). In humans, the maximum ATP production rate in the skeletal muscle appears to decline by $8 \%$ per decade due to a combination of reduced mitochondrial content and compromised function of the existing mitochondrial population (Short et al. 2005). Similarly, Conley et al. (2000) reported nearly $50 \%$ reduction in oxidative capacity of the vastus lateralis muscle in humans aged 65-80 compared to subjects ranging in age from 25 to 48 years (Conley et al. 2000). Also measurements of mitochondrial oxidative/phosphorylation activity based on ${ }^{13} \mathrm{C} /{ }^{31} \mathrm{P}$ nuclear magnetic resonance spectroscopy found approximately $40 \%$ reduction in mitochondrial oxidative and phosphorylation activity in elderly compared to young people (Petersen et al. 2003). Detailed analysis showed that activities of complexes I and IV were reduced, whereas activities of complexes II, III and V were mostly unaffected (Benzi et al. 1992, Boffoli et al. 1994, Chabi et al. 2005, Crane et al. 2010, Fattoretti et al. 2001, Kerner et al. 2001, Kumaran et al. 2005, Larsson 2010, Pastoris et al. 2000, Tonkonogi et al. 2003). The likely reason is that the complexes I and IV are largely encoded by mtDNA that is more vulnerable and more susceptible to damage and mutation (Benzi et al. 1992, Boffoli et al. 1994, Chabi et al. 2005, Cooper et al. 1992, Crane et al. 2010, Kumaran et al. 2005, Larsson 
2010, Tonkonogi et al. 2003). The activities of citric acid cycle enzymes (isocitrate dehydrogenase, alphaketoglutarate dehydrogenase, succinate dehydrogenase, and malate dehydrogenase) were also found to be decreased in skeletal muscle of aged rats (Kumaran et al. 2005). In contrast, preserved muscle oxidative capacity was rarely reported in the human and mouse skeletal muscle (Kumaran et al. 2005, Larsson 2010).

Reduced capacity of the respiratory chain was reported not only in the cardiac and skeletal muscle, but also in the liver, brain, kidney, platelets and lung (AcuñaCastroviejo et al. 2012, Choksi et al. 2011, Ojaimi et al. 1999, Shi et al. 2010, Short et al. 2005). Ojaimi et al. (1999) documented an age-related fall in cytochrome $c$ oxidase (complex IV) activity in the frontal cortex, superior temporal cortex, cerebellum and putamen (Ojaimi et al. 1999). Yen et al. (1989) analyzed State 3 and State 4 respiration rates, respiratory control ratio, and $\mathrm{ADP} / \mathrm{O}$ ratio in human liver; their results showed decreasing respiratory control and $\mathrm{ADP} / \mathrm{O}$ ratios with the advancing age (Yen et al. 1989). Lenaz (1998) focused on the function of mitochondria in human platelets during aging and suggested the titre for half-inhibition of complex I by rotenone as a suitable biomarker of aging and age-related diseases (Lenaz 1998).

Some of the morphological and functional changes described above might be secondary as mitochondrial biogenesis and energy production are controlled at many different levels, e.g. by hormones. Receptors for glucocorticoids, oestrogens, androgens, and thyroid hormones have been detected in mitochondria of various cell types. Age-related decrease in the levels of hormones affecting directly or indirectly mitochondria may at least partly contribute to the overall decline in mitochondrial dynamics (Chen et al. 2009, Knuever et al. 2012, Psarra and Sekeris 2008, Scheller and Sekeris 2003, Weitzel et al. 2003). E.g. Knuever et al. (2012) identified thyrotropin-releasing hormone (TRH) as a potent novel neuroendocrine stimulator of mitochondrial activity and biogenesis in human: TRH significantly enhanced mitochondrial complex I and IV activities thereby increasing the oxygen consumption (Knuever et al. 2012).

\section{Mitochondrial DNA mutations in aging}

Typical metazoan mitochondrial genome (mtDNA) is a closed double-stranded circular molecule that varies in size among different species ranging from
$11.4 \mathrm{~kb}$ to $32.1 \mathrm{~kb}$ (Gissi et al. 2008). Structure and gene organization of mtDNA is highly conserved among mammals.

Human mitochondrial DNA spanning 16569 base pairs (Anderson et al. 1981) contains 37 genes coding for 2 rRNAs, 22 tRNAs and 13 polypeptides (that all are components of the oxidative phosphorylation system, Castellana et al. 2011). Individual strands of mtDNA differ in the base composition: the heavy strand is rich in guanines and encodes majority of mitochondrial genes (12 polypeptides, 2 rRNAs and 14 tRNAs), the light strand is rich in cytosines and carries genes for 1 polypeptide and 8 tRNAs (Clayton 2000). General view of the mitochondrial DNA structure is shown in Figure 1B. Because of the small size of mtDNA, there are only small portions of non-coding sequences like D-loop (playing crucial role in replication and transcription); genes are lacking introns and may overlap (Taanman 1999). Recently, novel non-coding transcripts originating from mitochondrial genome were discovered, but their function is yet to be elucidated (Rackham et al. 2011, Ro et al. 2013).

Mammalian cells, depending on their metabolic and functional activity, can contain hundreds to ten thousands of mtDNA molecules, with multiple copies per one mitochondria (Chinnery and Hudson 2013). Replication of mtDNA is independent of the cell replication and is performed by the DNA polymerase gamma (PolG), encoded by the nuclear gene POLG. PolG is a heterotrimeric complex of one catalytic and two accessory subunits (Kaguni 2004), which, in cooperation with DNA helicase Twinkle and single strand binding protein mtSSB, is sufficient to replicate mtDNA even in vitro (Korhonen et al. 2004).

MtDNA is organized, similarly to bacterial genomes, into nucleoids containing one to several copies of mtDNA molecules associated with DNA-binding proteins like mitochondrial transcription factor TFAM and others (Bogenhagen 2012). Association with proteins increases the protection of mtDNA against harmful agents, particularly ROS and reactive nitrogen molecules produced by mitochondrial metabolism (Gaziev et al. 2014), similarly to the protection of nuclear DNA by histone proteins.

Mitochondrial function is largely dependent on the supply of proteins coded by nuclear genome. Around 1500 proteins are estimated to be associated with mitochondria, depending on organism and tissue (Lotz et al. 2014). All proteins coded by mtDNA form crucial 
components for formation of electron transport complexes; in mtDNA, 7 subunits of complex I, 1 subunit of complex III, 3 subunits of complex IV and 2 subunits of complex V are encoded (Schon et al. 2012).

Changes in the mitochondrial genome in the form of point mutations as well as larger genome rearrangements like deletions arise over the lifespan of the organism. Important aspect influencing genesis of mtDNA mutations is the multicopy nature of mtDNA. Usually, only a portion of mtDNA molecules is mutated, creating the mtDNA heteroplasmy that can refer to both germinal and somatic mutations (Wallace and Chalkia 2013). Pathological manifestation of the mutation depends on so-called threshold effect - situation, where the accumulation of dysfunctional product reaches certain level and the mitochondria are further unable to perform essential functions (Rossignol et al. 2003).

Mutations in the mtDNA are accumulated over the lifespan of the organism faster than in the case of nuclear genome (Gaziev et al. 2014, Haag-Liautard et al. 2008). Factors contributing to the increased incidence of mtDNA mutations include: i) the lack of histones that are believed to reduce DNA damage in the nucleus; ii) chemical modification of mtDNA caused by intrinsic alkylation agents, ROS, reactive nitrogen species, some hormones and extrinsic toxic substances like ethanol, chemotherapeutic drugs and many others; iii) close proximity of mtDNA to the site of ROS production, i.e. the system of mitochondrial respiratory complexes; iv) number of available DNA repair systems that are much more limited in mitochondria than in the nucleus; v) deficiencies in 5'-3' proofreading capacity of PolG during the mtDNA replication that seem to be the major cause of mtDNA mutations (Alexeyev et al. 2013). This fact is supported by the observation that the mice strain mutated in PolG shows mutator phenotype with the rapid accumulation of mtDNA mutations and shortened lifespan (Kujoth 2005) and that in the older age, mutations caused by PolG mistakes rather than those induced by ROS are present (Kennedy et al. 2013).

Investigation of the direct effect of particular mtDNA mutation on aging is very difficult. Even in the old individuals, the total combined rate of mutations is very low, not reaching the estimated threshold for the manifestation of the mutation (Pinto and Moraes 2015). Most commonly studied tissues with respect to mtDNA mutagenesis are brain, cardiac and skeletal muscle or colonic crypt stem cells, where different mutations are formed and fixed. Even if the total level of mutated
mtDNA is low to affect the whole tissue, mutations can form "weak spots" that are able to paralyze the tissue function (Khrapko and Turnbull 2014).

\section{Reactive oxygen species and aging}

There are many sources of intracellular ROS in mammals, such as NADPH oxidases, xanthine oxidase, and monoamine oxidase; however, the mitochondrial electron transport system has been recognized as their major cellular generator (almost $90 \%$ of the total ROS produced in the cell) (Bratic and Trifunovic 2010, Dai et al. 2014, Liu et al. 2002). ROS are highly reactive molecules having potential to cause oxidative deterioration of proteins, lipids and DNA. ROS generate a variety of DNA lesions, such as oxidized DNA bases, abasic sites, oxidative DNA adducts, and DNA strand breaks (Cui et al. 2012).

In many studies dealing with aging processes, ROS have been suggested to be major mediators of ageassociated cellular damage in addition to be likely involved in the pathogenesis of some age-related neurodegenerative diseases such as Parkinson's disease and Alzheimer's disease (Bowling and Beal 1995, Good et al. 1996, Liu et al. 2002). Many theories of aging based on putative detrimental effects of ROS have been proposed, including the free radical and mitochondrial theories of aging (Chistiakov et al. 2014, Indo et al. 2015, Mikhed et al. 2015, Valerio and Nisoli 2015, Yan 2014). These theories speculate that cumulative damage to mitochondria caused by reactive radicals is a primary driving force of aging and major determinant of the lifespan. According to these hypotheses, mtDNA mutations caused by ROS alter the expression of oxidative phosphorylation complexes, which leads to limited mitochondrial respiratory enzymes activities, decrease in mitochondrial membrane potential and compromised production of ATP. Defective transport of electrons and their leak prior to the reduction of oxygen to water at cytochrome $c$ oxidase causes the production of superoxide. Two major sites for ROS generation are believed to be complexes I and III. Complex I is probably the most affected by ROS because seven of its subunits are encoded by mtDNA. Complex I activity is significantly affected by aging in rat brain and liver mitochondria as well as in human platelets (Genova et al. 2004). In turn, increased production of superoxide and related radicals leads to further oxidation stress-related changes in mitochondrial structure (accumulating 
vacuoles, cristae abnormalities), distribution, and dynamics that can result in critical mitochondrial dysfunction with ROS-accelerated ROS generation and even faster (Bratic and Trifunovic 2010).

Hypothesis of contribution of ROS to the processes of aging has been supported by genetic experiments. One of the master regulators of ROS production and oxidative stress is the isoform of the growth factor adapter (p66shc). The p66 ${ }^{\text {shc }}$ knockout mice, one of the best characterized genetic models of longevity, showed a considerable increase in the life span (Migliaccio et al. 1999). Also caloric restriction, through the modulation of IGF-1, TOR, sirtuins, and AMP kinase signaling pathways, has a beneficial impact on mitochondrial function and causes a significant reduction of mitochondrial ROS production. Downregulation of IGF-1 pathway is followed by the activation of FoxO transcription factors, which induces the transcription of antioxidant genes such as genes for antioxidant enzymes (Enns et al. 2008, Treuting et al. 2002, Vendelbo and Nair 2011).

Despite a large body of evidence supporting the role of ROS in aging, the free radical and mitochondrial theories of aging face some challenges as several experimental rodent and mice models of antioxidant manipulation have failed to affect the lifespan. Interestingly, a paradoxical increase in longevity was observed in mitochondrial respiration mutants of Caenorhabditis elegans at elevated levels of ROS (Cui et al. 2012, Yang and Hekimi 2010). Some studies focusing on experiments with long-lived rodents did not find any convincing correlation between the level of oxidative damage and aging (Panieri et al. 2013, Sena and Chandel 2012, Wu and Bratton 2013). In addition, although overexpression of mitochondrial Mn-superoxide dismutase (Mn-SOD) in Drosophila melanogaster extended the lifespan, murine overexpression of SOD1 did not affect it (Andziak et al. 2006, Cui et al. 2012, Dai et al. 2014, Huang et al. 2000). Manipulation with murine catalase targeted to mitochondria showed increased longevity while mice lacking Mn-SOD exhibited a $30 \%$ decrease in life expectancy and died from premature death associated with severe mitochondrial dysfunction and neurodegeneration (Cui et al. 2012, Lebovitz et al. 1996, Schriner et al. 2005, Sun et al. 2002).
Besides their detrimental roles, ROS seem to be more important as signaling molecules in regulation of the cell cycle progression, apoptosis, necrosis, growth arrest or senescence (Panieri et al. 2013, Sena and Chandel 2012, Wu and Bratton 2013). They were shown to activate transcription factor - hypoxia-induced factor-1 (HIF-1), which is associated with prolonged lifespan or to activate some tyrosine kinases, mitogen activated protein kinases or RAS proteins (Bratic and Larsson 2013, Cui et al. 2012). Based on these new findings, the gradual ROS response hypothesis of aging has been postulated (Hekimi et al. 2011), stating that ROS-induced stress response is essential for the maintenance of tissue homeostasis. In aging process, more stress is generated, leading to the increased production of ROS. When the certain threshold of ROS is reached, they start to add additional damage to the tissue, potentiating the tissue dysfunction and aging.

Taken together, more investigations are required to clarify the precise role that free radicals play in aging.

\section{Conclusions}

The role of mitochondria in the aging processes seems to be ambiguous - they initiate multiple processes leading to age-associated deterioration of the cellular functions and become targets of reactions leading to increased ROS generation, mtDNA mutations, oxidation of mitochondrial proteins with subsequent induction of apoptotic events, impaired oxidative phosphorylation capacity, mitochondrial dynamics, biogenesis and autophagy (Fig. 3). Studies using transgenic or knockout animals revealed many mitochondria-related factors potentially affecting longevity - uncoupling proteins, sirtuins, antioxidant enzymes, FOXO group of transcription factors, AMP-activated protein kinase etc. (Jang and Van Remmen 2009, Vendelbo and Nair 2011). Recently, various mouse models associated with severe mitochondrial dysfunction and premature aging have been reviewed (Grimm et al. 2016). In addition, genes having potential pro-longevity effects have been screened in Caenorhabditis elegans after mild mitochondrial stress (Maglioni et al. 2016). More work is needed to clarify their precise role in the process of natural aging and putative beneficial effects of their activators/inhibitors. 


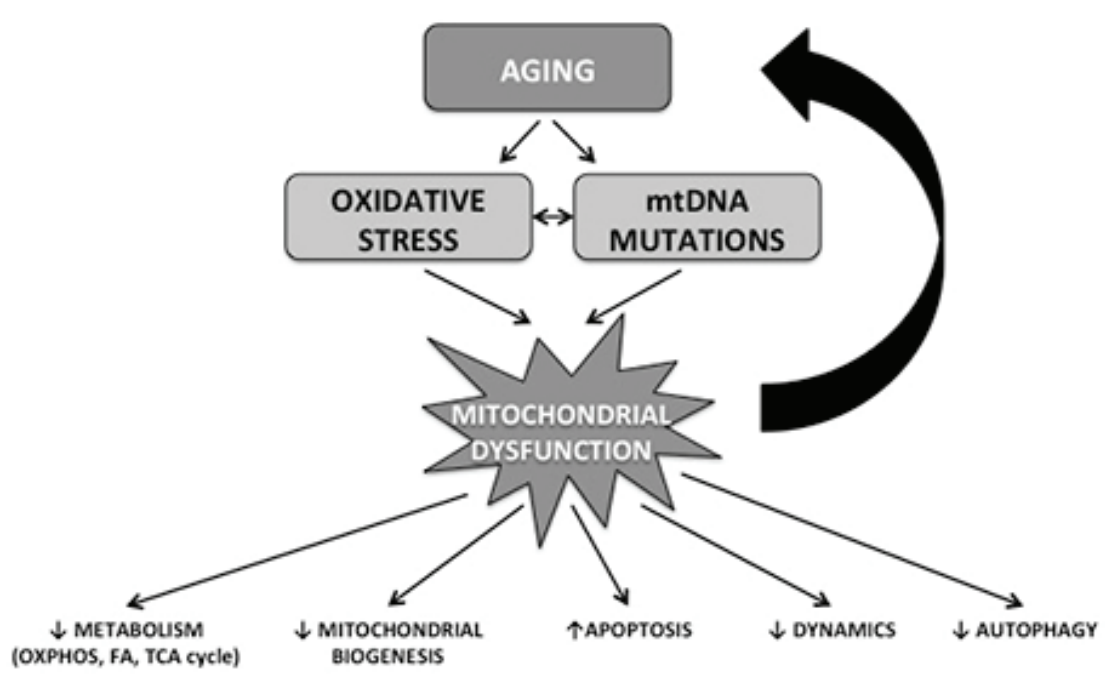

Fig. 3. Schematic view on effects of aging on mitochondrial dysfunction. OXPHOS oxidative phosphorylation, FA - fatty acids, TCA cycle - tricarboxylic acid cycle.

\section{Conflict of Interest}

There is no conflict of interest.

\section{Acknowledgements}

This study was supported by the National Sustainability Program I (NPU I) Nr. LO1503 provided by the
Ministry of Education Youth and Sports of the Czech Republic, the Charles University Research Fund (Nr. P36), the Specific Student Research Project Nr. 260281/2016 of the Charles University, Prague and by the project NT $14330-3 / 2013$.

\section{References}

ACUÑA-CASTROVIEJO D, CARRETERO M, DOERRIER C, LÓPEZ LC, GARCÍA-CORZO L, TRESGUERRES JA, ESCAMES G: Melatonin protects lung mitochondria from aging. Age Dordr Neth 34: 681-692, 2012.

ALEXEYEV M, SHOKOLENKO I, WILSON G, LEDOUX S: The maintenance of mitochondrial DNA integrity critical analysis and update. Cold Spring Harb Perspect Biol 5: a012641, 2013.

ALLEN SP, DUFFY LM, SHAW PJ, GRIERSON AJ: Altered age-related changes in bioenergetic properties and mitochondrial morphology in fibroblasts from sporadic amyotrophic lateral sclerosis patients. Neurobiol Aging 36: 2893-2903, 2015.

ANDERSON S, BANKIER AT, BARRELL BG, DE BRUIJN MH, COULSON AR, DROUIN J, EPERON IC, NIERLICH DP, ROE BA, SANGER F, SCHREIER PH, SMITH AJ, STADEN R, YOUNG IG: Sequence and organization of the human mitochondrial genome. Nature 290: 457-465, 1981.

ANDZIAK B, O'CONNOR TP, QI W, DEWAAL EM, PIERCE A, CHAUDHURI AR, VAN REMMEN H, BUFFENSTEIN R: High oxidative damage levels in the longest-living rodent, the naked mole-rat. Aging Cell 5: 463-471, 2006.

ANTON SD, WOODS AJ, ASHIZAWA T, BARB D, BUFORD TW, CARTER CS, CLARK DJ, COHEN RA, CORBETT DB, CRUZ-ALMEIDA Y, DOTSON V, EBNER N, EFRON PA, FILLINGIM RB, FOSTER TC, GUNDERMANN DM, JOSEPH AM, KARABETIAN C, LEEUWENBURGH C, MANINI TM, MARSISKE M, MANKOWSKI RT, MUTCHIE HL, PERRI MG, RANKA S, RASHIDI P, SANDESARA B, SCARPACE PJ, SIBILLE KT, SOLBERG LM, SOMEYA S, UPHOLD C, WOHLGEMUTH S, WU SS, PAHOR M: Successful aging: advancing the science of physical independence in older adults. Ageing Res Rev 24: 304-327, 2015.

AVANTAGGIATO A, BERTUZZI G, PASCALI M, CANDOTTO V, CARINCI F: The theories of aging: reactive oxygen species and what else? J Biol Regul Homeost Agents 29: 156-163, 2015.

BARJA G: Updating the mitochondrial free radical theory of aging: an integrated view, key aspects, and confounding concepts. Antioxid Redox Signal 19: 1420-1445, 2013. 
BARRIENTOS A, CASADEMONT J, RÖTIG A, MIRÓ O, URBANO-MÁRQUEZ A, RUSTIN P, CARDELLACH F: Absence of relationship between the level of electron transport chain activities and aging in human skeletal muscle. Biochem Biophys Res Commun 229: 536-539, 1996.

BASARIA S: Reproductive aging in men. Endocrinol Metab Clin North Am 42: 255-270, 2013.

BAUMGARTNER RN, KOEHLER KM, GALLAGHER D, ROMERO L, HEYMSFIELD SB, ROSS RR, GARRY PJ, LINDEMAN RD: Epidemiology of sarcopenia among the elderly in New Mexico. Am J Epidemiol 147: 755-763, 1998.

BENARD G, FAUSTIN B, PASSERIEUX E, GALINIER A, ROCHER C, BELLANCE N, DELAGE J-P, CASTEILLA L, LETELLIER T, ROSSIGNOL R: Physiological diversity of mitochondrial oxidative phosphorylation. Am J Physiol Cell Physiol 291: C1172-C1182, 2006.

BENZI G, PASTORIS O, MARZATICO F, VILLA RF, DAGANI F, CURTI D: The mitochondrial electron transfer alteration as a factor involved in the brain aging. Neurobiol Aging 13: 361-368, 1992.

BEREGI E, REGIUS O, HÜTTL T, GÖBL Z: Age-related changes in the skeletal muscle cells. Z Gerontol 21: 83-86, 1988.

BOFFOLI D, SCACCO SC, VERGARI R, SOLARINO G, SANTACROCE G, PAPA S: Decline with age of the respiratory chain activity in human skeletal muscle. Biochim Biophys Acta 1226: 73-82, 1994.

BOGENHAGEN DF: Mitochondrial DNA nucleoid structure. Biochim Biophys Acta 1819: 914-920, 2012.

BONOMINI F, RODELLA LF, REZZANI R: Metabolic syndrome, aging and involvement of oxidative stress. Aging Dis 6: 109-120, 2015.

BOUDINA S, GRAHAM TE: Mitochondrial function/dysfunction in white adipose tissue. Exp Physiol 99: 1168-1178, 2014.

BOWLING AC, BEAL MF: Bioenergetic and oxidative stress in neurodegenerative diseases. Life Sci 56: 1151-1171, 1995.

BRATIC A, LARSSON NG: The role of mitochondria in aging. J Clin Invest 123: 951-957, 2013.

BRATIC I, TRIFUNOVIC A: Mitochondrial energy metabolism and ageing. Biochim Biophys Acta 1797: 961-967, 2010.

BUA E, JOHNSON J, HERBST A, DELONG B, MCKENZIE D, SALAMAT S, AIKEN JM: Mitochondrial DNAdeletion mutations accumulate intracellularly to detrimental levels in aged human skeletal muscle fibers. $\mathrm{Am} J$ Hum Genet 79: 469-480, 2006.

CASTELLANA S, VICARIO S, SACCONE C: Evolutionary patterns of the mitochondrial genome in Metazoa: exploring the role of mutation and selection in mitochondrial protein-coding genes. Genome Biol Evol 3: 1067-1079, 2011.

CHABI B, MOUSSON De CAMARET B, CHEVROLliER A, BOISGARD S, STEPIEN G: Random mtDNA deletions and functional consequence in aged human skeletal muscle. Biochem Biophys Res Commun 332: 542-549, 2005.

CHEN JQ, CAMMARATA PR, BAINES CP, YAGER JD: Regulation of mitochondrial respiratory chain biogenesis by estrogens/estrogen receptors and physiological, pathological and pharmacological implications. Biochim Biophys Acta 1793: 1540-1570, 2009.

CHINNERY PF, HUDSON G: Mitochondrial genetics. Br Med Bull 106: 135-159, 2013.

CHISTIAKOV DA, SOBENIN IA, REVIN VV, OREKHOV AN, BOBRYSHEV YV: Mitochondrial aging and age-related dysfunction of mitochondria. BioMed Res Int 2014: 238463, 2014.

CHOKSI KB, NUSS JE, DEFORD JH, PAPACONSTANTINOU J: Mitochondrial electron transport chain functions in long-lived Ames dwarf mice. Aging 3: 754-767, 2011.

CLAYTON DA: Transcription and replication of mitochondrial DNA. Hum Reprod 15 (Suppl 2): 11-17, 2000.

CONLEY KE, JUBRIAS SA, ESSELMAN PC: Oxidative capacity and ageing in human muscle. $J$ Physiol 526: 203-210, 2000.

COOPER JM, MANN VM, SCHAPIRA AH: Analyses of mitochondrial respiratory chain function and mitochondrial DNA deletion in human skeletal muscle: effect of ageing. J Neurol Sci 113: 91-98, 1992. 
CRANE JD, DEVRIES MC, SAFDAR A, HAMADEH MJ, TARNOPOLSKY MA: The effect of aging on human skeletal muscle mitochondrial and intramyocellular lipid ultrastructure. J Gerontol A Biol Sci Med Sci 65 : 119-128, 2010.

CUI H, KONG Y, ZHANG H: Oxidative stress, mitochondrial dysfunction, and aging. J Signal Transduct 2012: 646354, 2012.

DAI DF, CHIAO YA, MARCINEK DJ, SZETO HH, RABINOVITCH PS: Mitochondrial oxidative stress in aging and healthspan. Longev Heal 3: 6, 2014.

ENNS LC, WILEY JC, LADIGES WC: Clinical relevance of transgenic mouse models for aging research. Crit Rev Eukaryot Gene Expr 18: 81-91, 2008.

FATTORETTI P, VECCHIET J, FELZANI G, GRACCIOTTI N, SOLAZZI M, CASELLI U, BERTONI-FREDDARI $\mathrm{C}$ : Succinic dehydrogenase activity in human muscle mitochondria during aging: a quantitative cytochemical investigation. Mech Ageing Dev 122: 1841-1848, 2001.

FIGUEIREDO PA, MOTA MP, APPELL HJ, DUARTE JA: The role of mitochondria in aging of skeletal muscle. Biogerontology 9: 67-84, 2008.

FRIEDMAN JR, NUNNARI J: Mitochondrial form and function. Nature 505: 335-343, 2014.

FULOP T, LARBI A, WITKOWSKI JM, MCELHANEY J, LOEB M, MITNITSKI A, PAWELEC G: Aging, frailty and age-related diseases. Biogerontology 11: 547-563, 2010.

GAZIEV AI, ABDULLAEV S, PODLUTSKY A: Mitochondrial function and mitochondrial DNA maintenance with advancing age. Biogerontology 15: 417-438, 2014.

GENOVA ML, PICH MM, BERNACCHIA A, BIANCHI C, BIONDI A, BOVINA C, FALASCA AI, FORMIGGINI G, CASTELLI GP, LENAZ G: The mitochondrial production of reactive oxygen species in relation to aging and pathology. Ann N Y Acad Sci 1011: 86-100, 2004.

GISSI C, IANNELLI F, PESOLE G: Evolution of the mitochondrial genome of Metazoa as exemplified by comparison of congeneric species. Heredity 101: 301-320, 2008.

GNAIGER E: Capacity of oxidative phosphorylation in human skeletal muscle: new perspectives of mitochondrial physiology. Int J Biochem Cell Biol 41: 1837-1845, 2009.

GONZALEZ-FREIRE M, DE CABO R, BERNIER M, SOLLOTT SJ, FABBRI E, NAVAS P, FERRUCCI L: Reconsidering the role of mitochondria in aging. J Gerontol A Biol Sc Med Sci 70: 1334-1342, 2015.

GOOD PF, WERNER P, HSU A, OLANOW CW, PERL DP: Evidence of neuronal oxidative damage in Alzheimer's disease. Am J Pathol 149: 21-28, 1996.

GRIMM A, FRIEDLAND K, ECKERT A: Mitochondrial dysfunction: the missing link between aging and sporadic Alzheimer's disease. Biogerontology 17: 281-296, 2016.

HAAG-LIAUTARD C, COFFEY N, HOULE D, LYNCH M, CHARLESWORTH B, KEIGHTLEY PD: Direct estimation of the mitochondrial DNA mutation rate in Drosophila melanogaster. PLoS Biol 6: e204, 2008.

HARMAN D: Aging: a theory based on free radical and radiation chemistry. J Gerontol 11: 298-300, 1956.

HEKIMI S, LAPOINTE J, WEN Y: Taking a "good" look at free radicals in the aging process. Trends Cell Biol 21: 569-576, 2011.

HELLER A, BROCKHOFF G, GOEPFERICH A: Targeting drugs to mitochondria. Eur J Pharm Biopharm 82: 1-18, 2012.

HUANG TT, CARLSON EJ, GILLESPIE AM, SHI Y, EPSTEIN CJ: Ubiquitous overexpression of CuZn superoxide dismutase does not extend life span in mice. J Gerontol A Biol Sci Med Sci 55: 5-9, 2000.

INDO HP, YEN HC, NAKANISHI I, MATSUMOTO K, TAMURA M, NAGANO Y, MATSUI H, GUSEV O, CORNETTE R, OKUDA T, MINAMIYAMA Y, ICHIKAWA H, SUENAGA S, OKI M, SATO T, OZAWA T, CLAIR DK, MAJIMA HJ: A mitochondrial superoxide theory for oxidative stress diseases and aging. $J$ Clin Biochem Nutr 56: 1-7, 2015.

JANG YC, VAN REMMEN H: The mitochondrial theory of aging: insight from transgenic and knockout mouse models. Exp Gerontol 44: 256-260, 2009.

KAGUNI LS: DNA polymerase gamma, the mitochondrial replicase. Annu Rev Biochem 73: 293-320, 2004.

KENNEDY SR, SALK JJ, SCHMITT MW, LOEB LA: Ultra-sensitive sequencing reveals an age-related increase in somatic mitochondrial mutations that are inconsistent with oxidative damage. PLoS Genet 9: e1003794, 2013. 
KERNER J, TURKALY PJ, MINKLER PE, HOPPEL CL: Aging skeletal muscle mitochondria in the rat: decreased uncoupling protein-3 content. Am J Physiol Endocrinol Metab 281: 1054-1062, 2001.

KHRAPKO K, TURNBULL D: Mitochondrial DNA mutations in aging. Prog Mol Biol Transl Sci 127: 29-62, 2014.

KNUEVER J, POEGGELER B, GÁSPÁR E, KLINGER M, HELLWIG-BURGEL T, HARDENBICKER C, TÓTH BI, BÍRÓ T, PAUS R: Thyrotropin-releasing hormone controls mitochondrial biology in human epidermis. $J$ Clin Endocrinol Metab 97: 978-986, 2012.

KORHONEN JA, PHAM XH, PELLEGRINI M, FALKENBERG M: Reconstitution of a minimal mtDNA replisome in vitro. EMBO J 23: 2423-2429, 2004.

KUJOTH GC: Mitochondrial DNA mutations, oxidative stress, and apoptosis in mammalian aging. Science 309: 481-484, 2005.

KUMARAN S, SUBATHRA M, BALU M, PANNEERSELVAM C: Supplementation of L-carnitine improves mitochondrial enzymes in heart and skeletal muscle of aged rats. Exp Aging Res 31: 55-67, 2005.

LANZA IR, SHORT DK, SHORT KR, RAGHAVAKAIMAL S, BASU R, JOYNER MJ, MCCONNELL JP, NAIR KS: Endurance exercise as a countermeasure for aging. Diabetes 57: 2933-2942, 2008.

LARSSON NG: Somatic mitochondrial DNA mutations in mammalian aging. Annu Rev Biochem 79: 683-706, 2010.

LEBOVITZ RM, ZHANG H, VOGEL H, CARTWRIGHT J, DIONNE L, LU N, HUANG S, MATZUK MM: Neurodegeneration, myocardial injury, and perinatal death in mitochondrial superoxide dismutase-deficient mice. Proc Natl Acad Sci USA 93: 9782-9787, 1996.

LENAZ G: Role of mitochondria in oxidative stress and ageing. Biochim Biophys Acta 1366: 53-67, 1998.

LIU JP: Molecular mechanisms of ageing and related diseases. Clin Exp Pharmacol Physiol 41: 445-458, 2014.

LIU Y, FISKUM G, SCHUBERT D: Generation of reactive oxygen species by the mitochondrial electron transport chain. J Neurochem 80: 780-787, 2002.

LOGAN DC: The mitochondrial compartment. $J$ Exp Bot 57: 1225-1243, 2006.

LÓPEZ-LLUCH G, SANTOS-OCAÑA C, SÁNCHEZ-ALCÁZAR JA, FERNÁNDEZ-AYALA DJM, ASENCIOSALCEDO C, RODRÍGUEZ-AGUILERA JC, NAVAS P: Mitochondrial responsibility in ageing process: innocent, suspect or guilty. Biogerontology 16: 599-620, 2015.

LOTZ C, LIN AJ, BLACK CM, ZHANG J, LAU E, DENG N, WANG Y, ZONG NC, CHOI JH, XU T, LIEM DA, KORGE P, WEISS JN, HERMJAKOB H, YATES JR, APWEILER R, PING R: Characterization, design, and function of the mitochondrial proteome: from organs to organisms. J Proteome Res 13: 433-446, 2014.

MAGLIONI S, ARSALAN N, VENTURA N: C. elegans screening strategies to identify pro-longevity interventions. Mech Ageing Dev 157: 60-69, 2016.

MAHMOUD YI, HEGAZY HG: Ginger and alpha lipoic acid ameliorate age-related ultrastructural changes in rat liver. Biotech Histochem 91: 86-95, 2016.

MARYCZ K, KORNICKA K, BASINSKA K, CZYREK A: Equine metabolic syndrome affects viability, senescence, and stress factors of equine adipose-derived mesenchymal stromal stem cells: new insight into EqASCs isolated from EMS horses in the context of their aging. Oxid Med Cell Longev 2016: 4710326, 2016.

MARZETTI E, HWANG JCY, LEES HA, WOHLGEMUTH SE, DUPONT-VERSTEEGDEN EE, CARTER CS, BERNABEI R, LEEUWENBURGH C: Mitochondrial death effectors: relevance to sarcopenia and disuse muscle atrophy. Biochim Biophys Acta 1800: 235-244, 2010.

MIGLIACCIO E, GIORGIO M, MELE S, PELICCI G, REBOLDI P, PANDOLFI PP, LANFRANCONE L, PELICCI PG: The p66shc adaptor protein controls oxidative stress response and life span in mammals. Nature 402: 309-313, 1999.

MIKHED Y, DAIBER A, STEVEN S: Mitochondrial oxidative stress, mitochondrial DNA damage and their role in age-related vascular dysfunction. Int J Mol Sci 16: 15918-15953, 2015.

MOORE AZ, BIGGS ML, MATTEINI A, O'CONNOR A, MCGUIRE S, BEAMER BA, FALLIN MD, FRIED LP, WALSTON J, CHAKRAVARTI A, ARKING DE: Polymorphisms in the mitochondrial DNA control region and frailty in older adults. PloS One 5: e11069, 2010.

MURPHY MP: How mitochondria produce reactive oxygen species. Biochem J 417: 1-13, 2009.

NAVARRO A, BOVERIS A: The mitochondrial energy transduction system and the aging process. Am J Physiol Cell Physiol 292: C670-C686, 2007. 
OJAIMI J, MASTERS CL, OPESKIN K, MCKELVIE P, BYRNE E: Mitochondrial respiratory chain activity in the human brain as a function of age. Mech Ageing Dev 111: 39-47, 1999.

OLSHANSKY SJ: Can a lot more people live to one hundred and what if they did? Accid Anal Prev 61: 141-145, 2013.

PALMER CS, OSELLAME LD, STOJANOVSKI D, RYAN MT: The regulation of mitochondrial morphology: intricate mechanisms and dynamic machinery. Cell Signal 23: 1534-1545, 2011.

PALOMERA-AVALOS V, GRIÑÁN-FERRÉ C, PUIGORIOL-ILAMOLA D, CAMINS A, SANFELIU C, CANUDAS AM, PALLÀS M: Resveratrol protects SAMP8 brain under metabolic stress: focus on mitochondrial function and Wnt pathway. Mol Neurobiol 2016. doi: 10.1007/s12035-016-9770-0

PANIERI E, GOGVADZE V, NORBERG E, VENKATESH R, ORRENIUS S, ZHIVOTOVSKY B: Reactive oxygen species generated in different compartments induce cell death, survival, or senescence. Free Radic Biol Med 57: 176-187, 2013.

PAPÁČKOVÁ Z, CAHOVÁ M: Important role of autophagy in regulation of metabolic processes in health, disease and aging. Physiol Res 63: 409-420, 2014.

PASTORIS O, BOSCHI F, VERRI M, BAIARDI P, FELZANI G, VECCHIET J, DOSSENA M, CATAPANO M: The effects of aging on enzyme activities and metabolite concentrations in skeletal muscle from sedentary male and female subjects. Exp Gerontol 35: 95-104, 2000.

PAYNE BAI, CHINNERY PF: Mitochondrial dysfunction in aging: much progress but many unresolved questions. Biochim Biophys Acta 1847: 1347-1353, 2015.

PETERSEN KF, BEFROY D, DUFOUR S, DZIURA J, ARIYAN C, ROTHMAN DL, DIPIETRO L, CLINE GW, SHULMAN GI: Mitochondrial dysfunction in the elderly: possible role in insulin resistance. Science 300: 1140-1142, 2003.

PINTO M, MORAES CT: Mechanisms linking mtDNA damage and aging. Free Radic Biol Med 85: 250-258, 2015.

POGGI P, MARCHETTI C, SCELSI R: Automatic morphometric analysis of skeletal muscle fibers in the aging man. Anat Rec 217: 30-34, 1987.

PORTER C, HURREN NM, COTTER MV, BHATTARAI N, REIDY PT, DILLON EL, DURHAM WJ, TUVDENDORJ D, SHEFFIELD-MOORE M, VOLPI E, SIDOSSIS LS, RASMUSSEN BB, BØRSHEIM E: Mitochondrial respiratory capacity and coupling control decline with age in human skeletal muscle. Am $J$ Physiol Endocrinol Metab 309: 224-232, 2015.

PSARRA AMG, SEKERIS CE: Steroid and thyroid hormone receptors in mitochondria. IUBMB Life 60: 210-223, 2008.

RACKHAM O, SHEARWOOD AMJ, MERCER TR, DAVIES SMK, MATTICK JS, FILIPOVSKA A: Long noncoding RNAs are generated from the mitochondrial genome and regulated by nuclear-encoded proteins. RNA 17: 2085-2093, 2011.

RO S, MA H-Y, PARK C, ORTOGERO N, SONG R, HENNIG GW, ZHENG H, LIN Y-M, MORO L, HSIEH J-T, YAN W: The mitochondrial genome encodes abundant small noncoding RNAs. Cell Res 23: 759-774, 2013.

ROSSIGNOL R, FAUSTIN B, ROCHER C, MALGAT M, MAZAT J-P, LETELLIER T: Mitochondrial threshold effects. Biochem J 370: 751-762, 2003.

ROY M, REDDY PH, IIJIMA M, SESAKI H: Mitochondrial division and fusion in metabolism. Curr Opin Cell Biol 33: 111-118, 2015.

SCHELLER K, SEKERIS CE: The effects of steroid hormones on the transcription of genes encoding enzymes of oxidative phosphorylation. Exp Physiol 88: 129-140, 2003.

SCHIFF M, BÉNIT P, COULIBALY A, LOUBLIER S, EL-KHOURY R, RUSTIN P: Mitochondrial response to controlled nutrition in health and disease. Nutr Rev 69: 65-75, 2011.

SCHON EA, DIMAURO S, HIRANO M: Human mitochondrial DNA: roles of inherited and somatic mutations. Nat Rev Genet 13: 878-890, 2012.

SCHRINER SE, LINFORD NJ, MARTIN GM, TREUTING P, OGBURN CE, EMOND M, COSKUN PE, LADIGES W, WOLF N, VAN REMMEN H, WALLACE DC, RABINOVITCH PS: Extension of murine life span by overexpression of catalase targeted to mitochondria. Science 308: 1909-1911, 2005.

SENA LA, CHANDEL NS: Physiological roles of mitochondrial reactive oxygen species. Mol Cell 48: 158-167, 2012. 
SHI C, XIAO S, LIU J, GUO K, WU F, YEW DT, XU J: Ginkgo biloba extract EGb761 protects against agingassociated mitochondrial dysfunction in platelets and hippocampi of SAMP8 mice. Platelets 21: 373-379, 2010.

SHIGENAGA MK, HAGEN TM, AMES BN: Oxidative damage and mitochondrial decay in aging. Proc Natl Acad Sci USA 91: 10771-10778, 1994.

SHORT KR, BIGELOW ML, KAHL J, SINGH R, COENEN-SCHIMKE J, RAGHAVAKAIMAL S, NAIR KS: Decline in skeletal muscle mitochondrial function with aging in humans. Proc Natl Acad Sci USA 102: 5618-5623, 2005.

SHUM LC, WHITE NS, NADTOCHIY SM, DE MESY BENTLEY KL, BROOKES PS, JONASON JH, ELISEEV RA: Cyclophilin D knock-out mice show enhanced resistance to osteoporosis and to metabolic changes observed in aging bone. PloS One 11: e0155709, 2016.

SUN J, FOLK D, BRADLEY TJ, TOWER J: Induced overexpression of mitochondrial Mn-superoxide dismutase extends the life span of adult Drosophila melanogaster. Genetics 161: 661-672, 2002.

TAANMAN J-W: The mitochondrial genome: structure, transcription, translation and replication. Biochim Biophys Acta 1410: 103-123, 1999.

TERMAN A, KURZ T, NAVRATIL M, ARRIAGA EA, BRUNK UT: Mitochondrial turnover and aging of long-lived postmitotic cells: the mitochondrial-lysosomal axis theory of aging. Antioxid Redox Signal 12: 503-535, 2010.

TONKONOGI M, FERNSTRÖM M, WALSH B, JI LL, ROOYACKERS O, HAMMARQVIST F, WERNERMAN J, SAHLIN K: Reduced oxidative power but unchanged antioxidative capacity in skeletal muscle from aged humans. Pflüg Arch 446: 261-269, 2003.

TREUTING PM, HOPKINS HC, WARE CA, RABINOVITCH PR, LADIGES WC: Generation of genetically altered mouse models for aging studies. Exp Mol Pathol 72: 49-55, 2002.

TURRENS JF: Mitochondrial formation of reactive oxygen species. J Physiol 552: 335-344, 2003.

VALERIO A, NISOLI E: Nitric oxide, interorganelle communication, and energy flow: a novel route to slow aging. Front Cell Dev Biol 3: 6, 2015.

VENDELBO MH, NAIR KS: Mitochondrial longevity pathways. Biochim Biophys Acta 1813: 634-644, 2011.

WALLACE DC, CHALKIA D: Mitochondrial DNA genetics and the heteroplasmy conundrum in evolution and disease. Cold Spring Harb Perspect Biol 5: a021220, 2013.

WANG C-H, WANG C-C, WEI Y-H: Mitochondrial dysfunction in insulin insensitivity: implication of mitochondrial role in type 2 diabetes. Ann N Y Acad Sci 1201: 157-165, 2010.

WEITZEL JM, IWEN KAH, SEITZ HJ: Regulation of mitochondrial biogenesis by thyroid hormone. Exp Physiol 88: 121-128, 2003.

WU C-C, BRATTON SB: Regulation of the intrinsic apoptosis pathway by reactive oxygen species. Antioxid Redox Signal 19: 546-558, 2013.

YAN LJ: Positive oxidative stress in aging and aging-related disease tolerance. Redox Biol 2: 165-169, 2014.

YANG W, HEKIMI S: A mitochondrial superoxide signal triggers increased longevity in Caenorhabditis elegans. PLoS Biol 8: e1000556, 2010.

YEN TC, CHEN YS, KING KL, YEH SH, WEI YH: Liver mitochondrial respiratory functions decline with age. Biochem Biophys Res Commun 165: 944-1003, 1989.

ZEVIANI M, Di DONATO S: Mitochondrial disorders. Brain J Neurol 127: 2153-2172, 2004.

ZHANG Y, ZENG X, JIN S: Autophagy in adipose tissue biology. Pharmacol Res 66: 505-512, 2012.

ZIEGLER DV, WILEY CD, VELARDE MC: Mitochondrial effectors of cellular senescence: beyond the free radical theory of aging. Aging Cell 14: 1-7, 2015. 